\title{
An apparently dominant bipolar affective disorder (BPAD) locus on chromosome 20p11.2-q11.2 in a large Turkish pedigree
}

\author{
U Radhakrishna ${ }^{1}$, S Senol $^{2}, \mathrm{H} \mathrm{Herken}^{3}, \mathrm{~K}$ Gucuyener $^{2}, \mathrm{C} \mathrm{Gehrig}^{1}$, J-L Blouin ${ }^{4}$, NA Akarsu ${ }^{5}$ \\ and SE Antonarakis ${ }^{1,4}$
}

\begin{abstract}
${ }^{1}$ Division of Medical Genetics, University of Geneva Medical School, Geneva, Switzerland; ${ }^{2}$ Departments of Psychiatry and Pediatric Neurology, Gazi University, Ankara; ${ }^{3}$ Department of Psychiatry, Gaziantep University, Gaziantep, Turkey; ${ }^{4}$ University Hospital, Geneva, Switzerland; ${ }^{5}$ DNA/C ell Bank and Gene Research Laboratory, Hacettepe University, Ankara, Turkey
\end{abstract}

Bipolar affective disorder (BPAD), also known as manic-depressive illness, is a common complex, polygenic disorder characterised by recurrent cyclic episodes of mania and depression. Family, twin, and adoption studies strongly suggest a genetic predisposition/susceptibility to BPAD, but no genes have yet been identified. We studied a large Turkish pedigree, with an apparently autosomal dominant BPAD, which contained 13 affected individuals. The age of onset ranged from 15-40 with a mean of 25 years. The phenotypes consisted of recurrent manic and major depressive episodes, including suicidal attempts; there was usually full remission with lithium treatment. A genome-wide linkage analysis using a dominant mode of inheritance showed strong evidence for a BPAD susceptibility locus on chromosome 20p11.2-q11.2. The highest 2-point lod score of 4.34 at $\theta=0$ was obtained with markers D20S604, D20S470, D20S836 and D20S838 using a dominant model with full penetrance. Haplotype analysis enabled the mapping of the BPAD locus in this family between markers D20S186 and D20S109, to a region of approximately $42 \mathrm{cM}$. European Journal of Human Genetics (2001) 9, 39-44.

Keywords: Bipolar affective disorder; manic-depressive illness; autosomal dominant; linkage analyses; human chromosome 20

\begin{abstract}
Introduction
Bipolar affective disorder (BPAD), also known as manicdepressive illness, is a common disease characterised by recurrent episodes of mania and major depression. The population lifetime prevalence of BPAD is approximately $0.5-1.5 \%$ and, if untreated, is associated with a $20-25 \%$ risk of suicide. ${ }^{1,2}$ Affective disorder has been known at least since the fourth century $\mathrm{BC}$, when Hippocrates coined the term melancholia, ${ }^{3}$ and the second century AD when Aretaeus of Cappadocia provided an excellent description. ${ }^{4}$
\end{abstract}

Correspondence: Professor SE Antonarakis, Division de Génétique Médicale, Centre Médical Universitaire, 1 rue Michel-Servet, 1211 Geneva 4, Switzerland. Tel: +4122 702 5708; Fax: +4122 702 5706; E-mail: Stylianos.Antonarakis@medecine.unige.ch Received 23 June 2000; revised 7 September 2000; accepted 22 September 2000
Family, twin, and adoption studies strongly implicate a hereditary component in the aetiology of BPAD, ${ }^{5}$ but to date no specific genes have been identified with mutations causing or predisposing to BPAD. A series of studies has been performed using linkage analyses in mostly small and medium-size families with BPAD. One chromosomal region with the strongest evidence for a BPAD susceptibility gene was found on $13 q 32$ with a maximum lod score of $3.5 ;{ }^{6}$ other regions with suggestive evidence for linkage were at $1 q 31-q 32,{ }^{6} \quad 4 p 16,{ }^{7,8} 4 q 35,{ }^{9} \quad 5 p 15.3,{ }^{10} \quad 6 p 24,,^{11} \quad 7 q 31,{ }^{6}$ $16 p 13,{ }^{12,13} 18 p 11.2^{6,14} 21 q 22.3^{15-17} 22 q 11-q 13 .{ }^{18}$

The ascertainment of occasional large families segregating a 'complex' trait such as BPAD is of considerable importance since it may reveal the existence of a single gene that in these families contributes considerably to the development of the phenotype. These genes may be minor contributors to the disease in the majority of the patients/families, perhaps via 
different, less deleterious mutations. However, their identification will undoubtedly contribute to the elucidation of the molecular pathophysiology of the disease. There are four examples of such families with positive linkage scores on $4 p$ $\left(\theta=4.1 ; \quad\right.$ marker D4S394), ${ }^{19} 21 \mathrm{q} 22 \quad(\theta=3.35$, marker D12S1260), ${ }^{15,20} 18 \mathrm{q} 22-\mathrm{q} 23(\theta=4.06$, marker D18S70 $),{ }^{21}$ and 12q23-q24 $\left(\theta=3.37\right.$, marker D12S1639). ${ }^{22}$

We studied a large Turkish BPAD pedigree, with an apparently autosomal dominant mode of inheritance. A genome-wide linkage analysis showed strong evidence for a BPAD susceptibility locus on chromosome20p11.2-q11.2, in a region of approximately $42 \mathrm{cM}$. The identification and characterisation of this BPAD gene will contribute to the elucidation of the molecular pathophysiology of this disease.

\section{Methods}

Family ascertainment, diagnosis and sample collection Family BP-TU1 originally from Konya, Turkey (Figure1A) with bipolar affective disorder and an apparent autosomal dominant mode of inheritance was first ascertained and diagnosed in 1986 through individual 17 in the psychiatric clinic of Gazi University, Ankara, Turkey. Further 12 years'

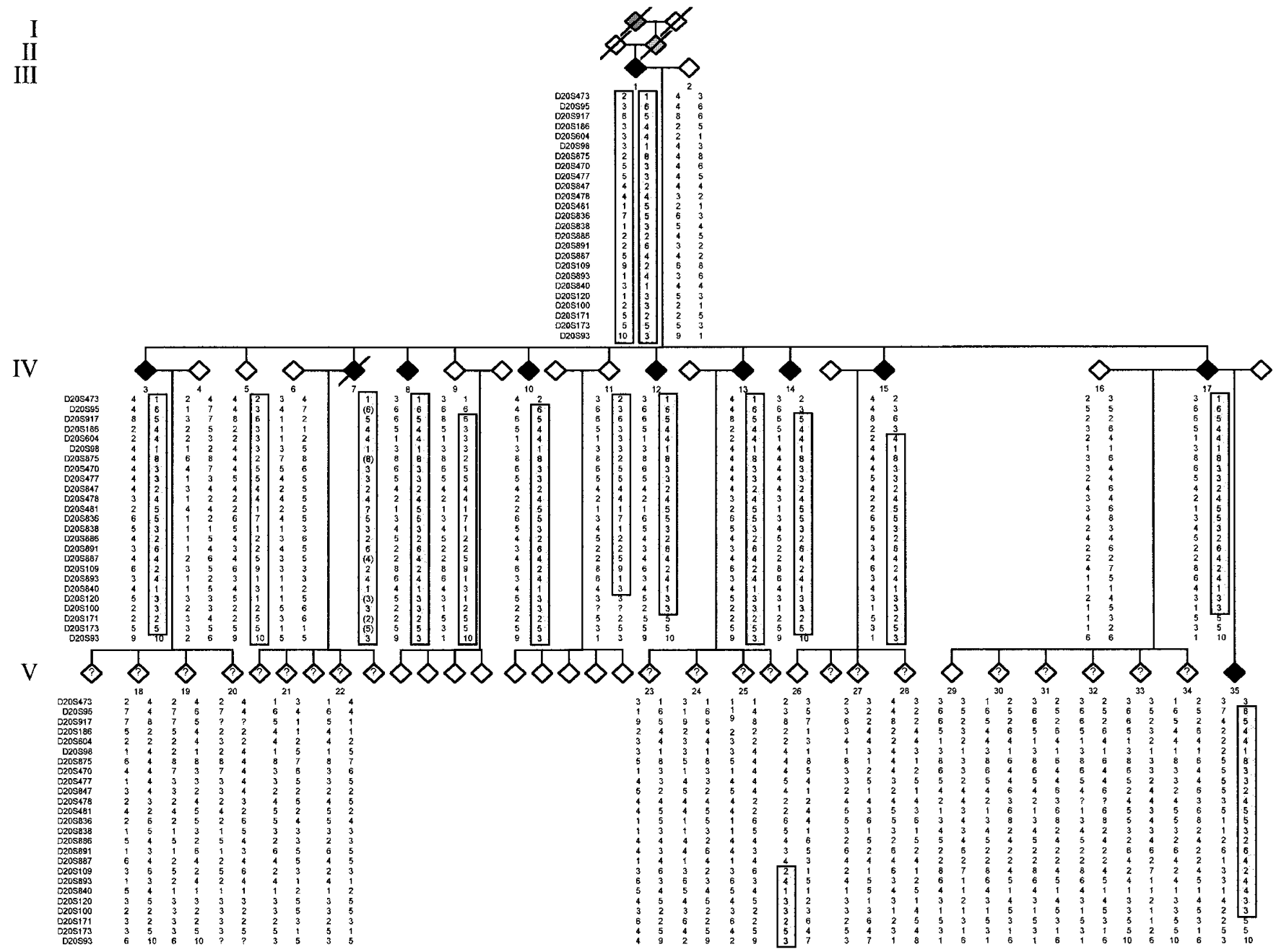

Figure 1 A Partial pedigree of BP-TU1 with bipolar affective disorder. Affecteds are shown will filled symbols and normals with clear symbols. Symbols in grey (generations I and II) refer to individuals affected according to the family history. Individuals used in the linkage analysis are numbered 1-35. ? indicates individuals below the cut-off age of 30 . To conceal the family identity, information related to sex, date of birth, and order of birth is not given and the order of individuals in the pedigree is intentionally mixed. This information could be made available to investigators on approval by the Geneva University Hospital and Gazi University, Turkey committees on research into human subjects. The genotypes and haplotypes of chromosome 20 markers are given below each individual. Haplotypes associated with affected status are boxed in grey. The haplotype of the diseased individual 7 was reconstructed from the data of individuals $1,2,6,21$, and 22 . The paternal or maternal origin of the alleles in parentheses could not be determined. Alleles of individual 7 were not used in the linkage analyses. 
follow up of different members of the pedigree demonstrated familial aggregation of the phenotype, and recently a field study has been performed to complete the pedigree analysis and to clinically evaluate additional individuals. The phenotypes were extensively characterised using DSM-IV criteria ${ }^{23}$ prior to genetic analysis. The clinical evaluation was performed with a Structured Clinical Interview from DSM-IV Clinical Version (SCID-I/CV). ${ }^{24,25}$ The diagnoses were determined after direct interviews, examination of medical records, family history, and extensive follow up of the patients by two psychiatrists (HH and SS) and a neurologist (KG). There was no discrepancy in the diagnoses. The age of onset ranged from 15 to 40 years with a mean of 25 years. The phenotypes consisted of recurrent manic and major depressive episodes, including suicidal attempts; there was usually full remission with lithium treatment. Tablel shows the DSM-IV diagnostic code and the age of onset for each affected member. The complete pedigree consists of 80 people with 11 affected available individuals (in generations III, IV and V) and it is partially shown in Figure $1 \mathrm{~A}$. The affected status of the deceased individuals of generations I and II has been provisionally assigned by family history taken from normal relatives. Among the 11 definite affected subjects there were eight females and three males. A total of 34 individuals were available at the time of field investigation. Ten were diagnosed with bipolar disease and one female had one episode of major depression. In generation $\mathrm{V}$, the majority of the descendants from affecteds is bel ow the mean age of onset of the disease and all of these individuals were viewed as unknown diagnosis for the linkage analysis. Individuals at risk that have not developed any symptoms after the age of 30 years (individuals 26 and 29 of Figure 1A) were considered unaffected.

\section{Genotyping and linkage analysis}

DNAs were isolated from blood samples of 34 individuals obtained after informed consent. The goals of the study were

Table 1 Phenotypic characteristics (DSM-IV diagnostic codes) of affected members of family BP-TU1. Individual IDS are in capital letters. The order of these letters does not correspond to the numbering of individuals in Figure $1 \mathrm{~A}$

\begin{tabular}{llllll}
\hline & $\begin{array}{l}\text { Age } \\
\text { onset } \\
\text { (years) }\end{array}$ & $\begin{array}{l}\text { Present } \\
\text { age } \\
\text { (years) }\end{array}$ & Sex & diagnosis & $\begin{array}{l}\text { DSM-IV } \\
\text { Axis I } \\
\text { codes }\end{array}$ \\
\hline A & 25 & 69 & M & Bipolar I & 296.45 \\
B & 15 & 42 & M & Bipolar I & 296.40 \\
C & 20 & 38 & M & Bipolar I & 296.04 \\
D & 40 & 53 & F & Bipolar I & 296.40 \\
E & 40 & 47 & F & Bipolar I & 296.89 \\
F & 25 & 48 & F & Bipolar I & 296.54 \\
G & 18 & 36 & F & Bipolar I & 296.56 \\
H & 15 & 34 & F & Bipolar I & 296.56 \\
I & 21 & 31 & F & Bipolar I & 296.46 \\
J & 19 & 28 & F & Bipolar I & 296.55 \\
K & 32 & 34 & F & Major depression & 296.25 \\
\hline
\end{tabular}

explained to each individual of the family, and written agreement was obtained from those who donated blood and had undergone psychiatric evaluation. Lymphoblastoid cell lines were established from selected individuals. For the systematic search of the genome-wide genotyping and linkage analysis we used 230 highly informative polymorphic markers covering the entire genome and selected from the Généthon (http://www.genethon.fr/) and CHLC collections (http://www.chlc.org/). ${ }^{26,29}$ The list of markers used is available upon E-mail request. The average heterozygosity of markers used was 0.76. DNA polymorphisms were detected by polymerase chain reaction (PCR) amplification and fragment analysis as described. ${ }^{30}$ Family information and marker genotypes were stored in computer program Cyrillic (Cherwell). Analysis was performed using the ILINK, MLINK and LINKMAP programs of LINKAGE v5.2 $2^{31}$ and FASTLINK v. $30^{32}$ software packages. Maximum lod scores were calculated for each marker by assuming several models including autosomal dominant mode of inheritance with $100 \%$ and $80 \%$ penetrance after the age of 30 years; a recessive model was also used.

\section{Results}

A genome-wide genotyping of 230 highly informative polymorphic markers evenly distributed throughout the human genome in all available members of the BP-TU1 pedigree was performed. Subsequent linkage analysis using a dominant mode of inheritance was either $100 \%$ or $80 \%$ penetrance and a threshold for the onset of the disease at 30 years of age, provided strong evidence for linkage of the BPAD susceptibility locus with markers on chromosome20p11.2-q11.2 (Figure 1B). The maximum lod score, $Z_{\max }=4.34$ at recombination fraction $\theta=0$ was obtained with markers D20S604, D20S470, D20S836 and D20S838 under 100\% penetrance (Table2). The maximum lod score for these markers using $80 \%$ penetrance was 4.05 . There was no difference in the maximum lod score when the gene frequency varied from 0.05 to 0.0001 . A total of 27 highly polymorphic markers covering the entire chromosome 20 and in particular the area of the positive lod scores, were then used to better define the interval of the BPAD susceptibility locus. Hapl otype analysis of polymorphic markers enabled the mapping of BPAD locus in the BP-TU1 family between markers D20S186 and D20S109 (by utilising informative recombinants from individuals 15 and 26) in a region of approximately $42 \mathrm{cM}$ (Figures 1, 2 and Table2).

Multipoint linkage analysis was performed by using three markers without recombination with the BPAD locus (D20S470, D20S836, and D20S891) and markers D20S186 and D20S109 with recombination. The map intervals used are shown in Table2. This analysis did not result in a lod score greater than the 2-point analysis.

No other genomic region resulted in a positive lod score including all the chromosomal intervals in which suggestive 
Table 2 Two-point lod scores between BPAD locus in family BP-TU1 and several chromosome 20p11-q13 polymorphic markers at various recombination fractions and $100 \%$ penetrance. The maximum lod score for $80 \%$ penetrance is also shown for $\theta=0$

\begin{tabular}{|c|c|c|c|c|c|c|c|c|c|c|c|c|}
\hline Markers & 0.0 & $\begin{array}{l}0.0 \\
(80 \%)\end{array}$ & 0.01 & 0.05 & 0.1 & 0.2 & 0.3 & 0.4 & $Z_{\max }$ & $\theta$ & $\begin{array}{l}\text { Marshfield } \\
\text { (cM) }\end{array}$ & $\begin{array}{l}\text { CHLC } \\
\text { (cM) }\end{array}$ \\
\hline D20S473 & $-\propto$ & -11.84 & -7.71 & -3.69 & -2.12 & -0.81 & -0.29 & -0.09 & 0.10360 & 0.647 & 0.0 & \\
\hline D20S95 & $-\propto$ & -6.86 & -4.49 & -1.81 & -0.77 & 0.03 & 0.25 & 0.17 & 0.37312 & 0.77 & 7.12 & 9.0 \\
\hline D20S917 & $-\propto$ & -5.34 & 2.03 & 2.46 & 2.41 & 1.96 & 1.30 & 0.49 & 2.46802 & 0.062 & 8.05 & \\
\hline D20S186 & $-\propto$ & -3.76 & 2.27 & 2.70 & 2.65 & 2.20 & 1.54 & 0.72 & 2.71105 & 0.062 & 7.6 & \\
\hline D20S604 & 4.34 & 4.05 & 4.27 & 3.98 & 3.60 & 2.80 & 1.91 & 0.89 & 4.33935 & 0.0 & 0.64 & 26.6 \\
\hline D20S98 & 3.89 & 3.58 & 3.82 & 3.55 & 3.20 & 2.45 & 1.61 & 0.67 & 3.88705 & 0.0 & 0.0 & 4.64 \\
\hline D20S875 & 3.21 & 3.08 & 3.18 & 3.02 & 2.79 & 2.24 & 1.58 & 0.79 & 3.21441 & 0.0 & 1.07 & \\
\hline D20S470 & 4.34 & 4.05 & 4.27 & 3.98 & 3.60 & 2.80 & 1.91 & 0.89 & 4.33935 & 0.0 & 0.53 & 6.0 \\
\hline D20S477 & 3.89 & 3.51 & 3.82 & 3.55 & 3.20 & 2.45 & 1.61 & 0.67 & 3.88705 & 0.0 & 7.0 & \\
\hline D20S847 & 4.04 & 3.65 & 3.97 & 3.68 & 3.30 & 2.50 & 1.61 & 0.60 & 4.03832 & 0.0 & 11.56 & \\
\hline D20S478 & 1.03 & 0.83 & 1.01 & 0.94 & 0.84 & 0.65 & 0.45 & 0.24 & 1.02803 & 0.0 & 2.73 & 7.0 \\
\hline D20S481 & 4.16 & 3.81 & 4.09 & 3.80 & 3.43 & 2.62 & 1.73 & 0.72 & 4.16326 & 0.0 & 8.23 & 9.0 \\
\hline D20S836 & 4.34 & 4.05 & 4.27 & 3.98 & 3.60 & 2.80 & 1.91 & 0.89 & 4.33935 & 0.0 & 2.56 & \\
\hline D20S838 & 4.34 & 4.05 & 4.27 & 3.98 & 3.60 & 2.80 & 1.91 & 0.89 & 4.33935 & 0.0 & 0.0 & \\
\hline D20S886 & 1.03 & 0.83 & 1.01 & 0.94 & 0.84 & 0.65 & 0.45 & 0.24 & 1.02803 & 0.0 & 1.28 & \\
\hline D20S891 & 3.80 & 3.58 & 3.73 & 3.46 & 3.11 & 2.35 & 1.52 & 0.58 & 3.79528 & 0.0 & 0.55 & \\
\hline D20S109 & $-\propto$ & 3.35 & 2.27 & 2.70 & 2.65 & 2.20 & 1.54 & 0.72 & 2.71105 & 0.062 & 2.2 & 10.5 \\
\hline D20S893 & $-\propto$ & 3.35 & 2.27 & 2.70 & 2.65 & 2.20 & 1.54 & 0.72 & 2.71105 & 0.062 & 3.28 & \\
\hline D20S840 & $-\propto$ & 3.05 & 1.98 & 2.42 & 2.39 & 1.99 & 1.39 & 0.64 & 2.43897 & 0.066 & 2.16 & \\
\hline D20S120 & $-\propto$ & 1.32 & 1.22 & 1.76 & 1.84 & 1.63 & 1.19 & 0.60 & 1.84129 & 0.092 & 3.6 & \\
\hline D20S100 & $-\propto$ & 2.88 & 1.80 & 2.25 & 2.22 & 1.82 & 1.22 & 0.47 & 2.26288 & 0.066 & 1.27 & \\
\hline D20S171 & $-\propto$ & -6.08 & -1.49 & -0.20 & 0.25 & 0.49 & 0.41 & 0.17 & 0.49491 & 0.214 & 10.92 & \\
\hline D20S173 & $-\propto$ & -0.12 & -1.24 & -0.54 & -0.26 & -0.03 & 0.06 & 0.06 & -6.60030 & 0.352 & 2.39 & 21.2 \\
\hline \multirow[t]{2}{*}{ D20S93 } & $-\propto$ & -6.14 & -7.71 & -3.69 & -2.12 & -0.79 & -0.23 & -0.01 & -2.04090 & 0.453 & 0.0 & 4.7 \\
\hline & & & & & & & & & Total & & 87.93 & 101.3 \\
\hline
\end{tabular}

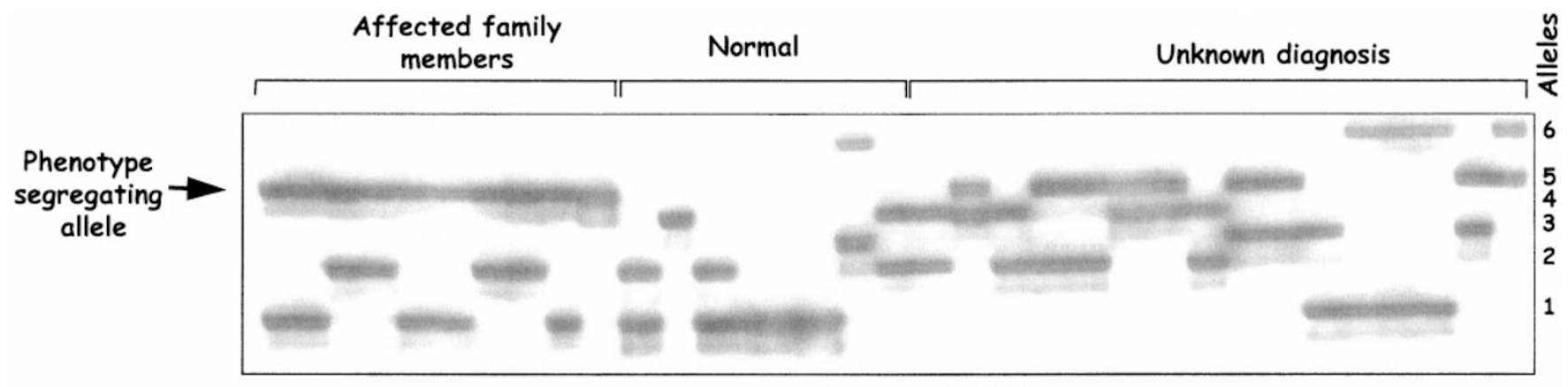

\section{Marker D20S481}

Figure 1 B Representative genotypes for the polymorphic microsatellite marker D20S481 in family BP-TU1. All affected individuals share polymorphic allele 5 of this marker.

evidence for linkage were previously reported. The highest lod scores obtained per chromosome using a dominant model with $100 \%$ penetrance are shown in Table3. The twopoint lod scores under recessive models were all negative.

\section{Discussion}

Linkage analysis of the BPAD susceptibility locus in the large Turkish pedigree (BP-TU1) with apparently autosomal dominant mode of inheritance showed that the disease locus maps to an approximately $42 \mathrm{cM}$ genomic interval between markers D20S186 and D20S109 on 20p11.2-q11.2. This interval could not be further narrowed down because no additional members from this family with definitive diagnoses were available for study. The diagnostic status of the majority of the individuals in generation $V$ was unknown since they are below the mean age of onset for BPAD in this family. A follow up in the next 10 years is needed to re-assess the phenotypes and better define the region on chromosome 20 with the potential BPAD susceptibility gene.

Linkage analysis (which we called conservative analysis) was also performed by setting the cut-off age of onset of the disease at age 40 years. In this scenario, individuals 26 and 29 in Figure $1 \mathrm{~A}$ were changed to unknown diagnostic status instead of unaffected. Furthermore, individual $\mathrm{K}$ in Table 1 who is now 34 years old and had only suffered a single 


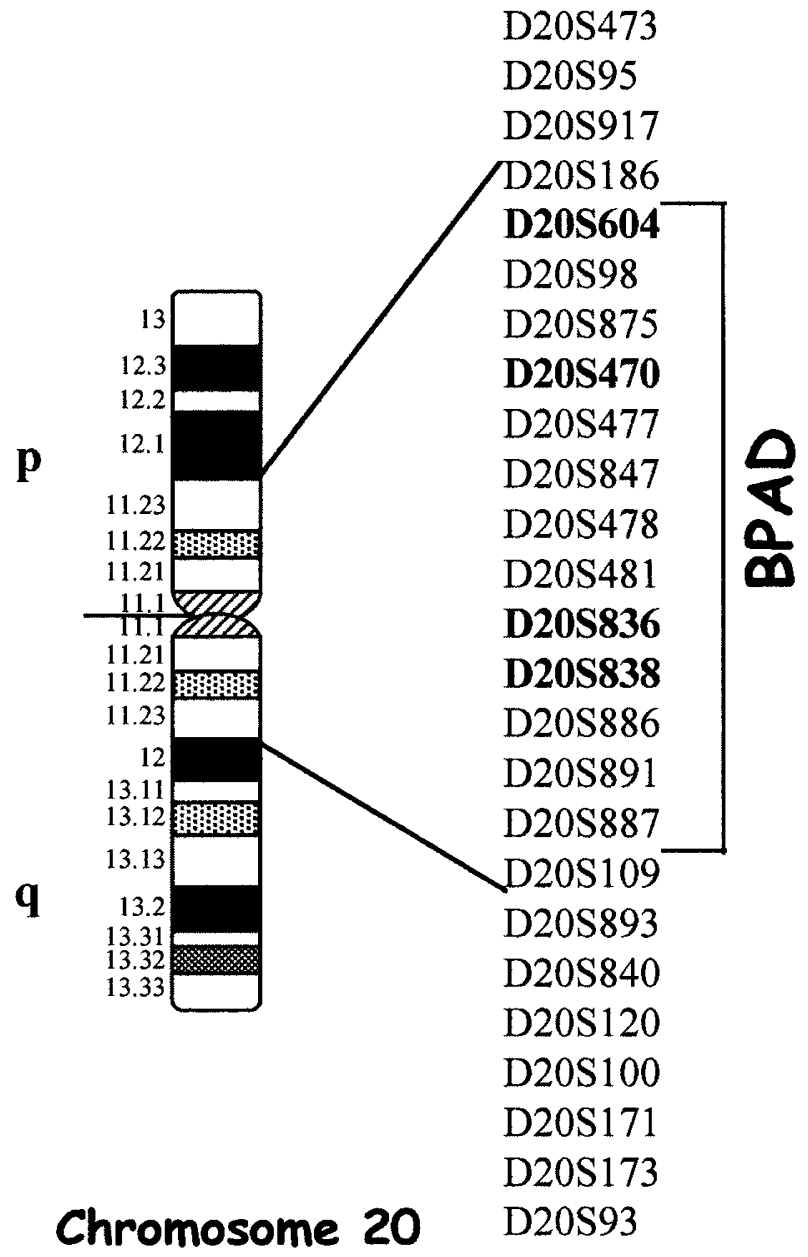

Figure 2 Schematic representation of human chromosome20. Cytogenetic localisation of the polymorphic microsatellite markers linked to the BPAD is indicated for the region 20pter-qter. The BPAD critical interval is bracketed where no detectable recombination with polymorphic markers is shown. The order of microsatellite markers is determined by using the Marshfield and CHLC linkage maps

(http://www.marshmed.org/genetics/ and http://www.chlc.org/).

episode of major depression at age 32 was coded as diagnosis unknown. Under this conservative model, the maximum lod scores for markers D20S604, D20S470, D20S836, D20S838, D20S109, D20S893, D20S840 was 3.44 at $\theta=0$, and the interval of the BPAD susceptibility locus was placed between markers D20S186 and D20S120 (after an informative recombinant in individual 11 ) in a region of $51 \mathrm{cM}$.

The large genomic interval between markers D20S186 and D20S109 on 20p11.2-q11.2 contains many putative genes and ESTs (http://www.ncbi.nlm.nih.gov/cgi-bin/ SCIENCE96/msrch2). Each of these genes and ESTs could be considered as a candidate for the BPAD susceptibility gene. Mutation analysis for each of these is required to first detect sequence variants and then determine which of these are
Table 3 Maximum lod scores and corresponding recombination fraction $(\theta)$ per chromosome obtained using a dominant model with $100 \%$ penetrance

\begin{tabular}{llll}
\hline Chromosome & Marker & $\begin{array}{l}\text { 2-point } \\
\text { lod score }\end{array}$ & Theta \\
\hline HC01 & D1S1595 & 1.2 & 0.091 \\
HC02 & D2S434 & 0.22 & 0.2 \\
HC03 & D3S2406 & 1.05 & 0.104 \\
HC04 & D4S2366 & 0.078 & 0.379 \\
HC05 & D5S1471 & 0.47 & 0.144 \\
HC06 & D6S1610 & 0.50 & 0.2 \\
HC07 & D7S2846 & 0.129 & 0.0 \\
HC08 & D8S1132 & 0.43 & 0.0 \\
HC08 & D8S1132 & 0.43 & 0.0 \\
HC09 & D9S1824 & 0.86 & 0.138 \\
HC10 & D10S1426 & 0.99 & 0.101 \\
HC11 & D11S1985 & 0.58 & 0.174 \\
HC12 & D12S1042 & 0.012 & 0.41 \\
HC13 & D13S1493 & 0.42 & 0.033 \\
HC14 & D14S617 & 0.23 & 0.264 \\
HC15 & D15S643 & 0.48 & 0.0 \\
HC15 & D15S653 & 0.85 & 0.148 \\
HC16 & D16S3253 & 0.42 & 0.0 \\
HC17 & D17S122 & 0.69 & 0.0 \\
HC18 & D18S59 & $-1.62 E-07$ & 0.5 \\
HC19 & D19S601 & 0.09 & 0.093 \\
HC20 & Several & 4.34 & 0.0 \\
HC21 & D21S1435 & 0.4 & 0.186 \\
HC22 & D22S420 & $-7.42 E-09$ & 0.5 \\
\hline
\end{tabular}

associated with the affected status in the members of the BP-TU1 family.

Was any chromosome20 BPAD susceptibility locus detected in the linkage analyses studies using small nuclear families? Detera-Wadleigh et al $^{33}$ performed a genome-wide scanning by using 540 individuals from 97 families which yielded a weakly increased allele-sharing in affected sibs with markers D20S604 on 20p ( $\leq \leq 0.05)$ and D20S173 on 20q $(P \leq 0.019)$. No linkage was found in the studies of Pakstis et $\mathrm{al}^{34}$ and Ewald et $\mathrm{al}^{35}$ where chromosome 20 markers were exclusively used. A more recent linkage analysis study of 22 multiplex pedigrees with 396 informative individuals and genotypes of 607 microsatellite markers ${ }^{6}$ did not reveal any lod score more than 1.00 for chromosome20 markers. These data suggest that the chromosome 20 BPAD susceptibility locus detected in family BP-TU1 is unlikely to be a major locus in the common 'polygenic' small pedigrees. This could be explained by the absence of common deleterious mutations of the chromosome 20 BPAD locus in the populations, and/or by the presence of a severe mutation in pedigree BP-TU1, that by itself confers susceptibility to BPAD.

The determination of the complete nucleotide sequence of chromosome 20 in the next 2 years will provide both a large number of SNPs spaced in intervals less than $100 \mathrm{~kb}^{36}$ (see also http://www.ncbi.nlm.nih.gov/SNP) and a list of all the genes in the BPAD critical region. Linkage disequilibrium, association studies, and mutation analyses may then determine the gene responsible for the phenotype, and the 
involvement of its encoded protein in the pathophysiology of this disease.

\section{Acknowledgements}

We thank HS Scott for his critical review of the manuscript, and all members of the BP-TU1 family for their co-operation and donation of blood samples. The study was supported by funds from the University and Cantonal Hospital of Geneva and (TUBITAK) DNA/Cell Bank and Gene Research Laboratory, Hacettepe University, Gazi University, Ankara, Gaziantep University, Gaziantep, Turkey.

\section{References}

1 Goodwin FK, Jamison KR: Manic-D epressive IIIness. Oxford University Press: New York, 1990.

2 Regier DA, Narrow WE, Rae DS et al: The de facto US mental and addictive disorders service system. Epidemiologic catchment area prospective 1-year prevalence rates of disorders and services. Arch Gen Psychiatry 1993; 50: 85-94.

3 [Hippocrates], Works of Hippocrates 4 vols, trans. and ed. WHS Jones and ET Witington. (Cambridge: Harvard University Press, 1923-1931), 36: 127-131; 2: 139-153.

4 [Aretaeus], The extant works of Aretaeus, the Cappadocian, trans. and ed. Francis Adams (London: Sydenham Society, 1856), pp 298-299.

5 Craddock N, Jones I: Genetics of bipolar disorder. J Med Genet 1999; 36: 585-594.

6 Detera-Wadleigh SD, Badner JA, Berrettini WH et al: A highdensity genome scan detects evidence for a bipolar-disorder susceptibility locus on 13q32 and other potential loci on 1q32 and 18p11.2. Proc Natl Acad Sci USA 1999; 96: 5604-5609.

7 Ewald H, Degn B, Mors O, Kruse TA: Support for the possible locus on chromosome4p16 for bipolar affective disorder. Mol Psychiatry 1998; 3: 442-448.

8 Ginns El, St Jean P, Philibert RA et al: A genome-wide search for chromosomal loci linked to mental health wellness in relatives at high risk for bipolar affective disorder among the Old Order Amish. Proc Natl Acad Sci USA 1998; 95: 15531-15536.

9 Adams LJ, Mitchell PB, Fielder SL et al: A susceptibility locus for bipolar affective disorder on chromosome4q35. Am J Hum Genet 1998; 62: 1084-1091.

10 KelsoeJR, Sadovnick AD, Kristbjarnarson $\mathrm{H}$ et al: Possible locus for bipolar disorder near the dopamine transporter on chromosome 5. Am J Med Genet 1996; 67: 533-540.

11 Ginns El, Ott J, Egeland JA et al: A genome-wide search for chromosomal loci linked to bipolar affective disorder in the Old Order Amish. Nat Genet 1996; 12: 431-435.

12 Eiberg H, Ewald H, M ors O: Suggestion of linkage between manicdepressive illness and the enzyme phosphoglycolate phosphatase (PGP) on chromosome16p. Clin Genet 1993; 44: 254-257.

13 Ewald $\mathrm{H}$, Mors $\mathrm{O}$, Flint $\mathrm{T}$ et al: A possible locus for manic depressive illness on chromosome16p13. Psychiatr Genet 1995; 5: 71-81.

14 Berrettini WH, Ferraro TN, Goldin LR et al: Chromosome18 DNA markers and manic-depressive illness: evidence for a susceptibility gene. Proc Natl Acad Sci USA 1994; 91: 5918-5921.

15 Straub RE, Lehner T, Luo $Y$ et al: A possible vulnerability locus for bipolar affective disorder on chromosome21q22.3. Nat Genet 1994; 8: 291-296.

16 Vallada H, Craddock N, Vasques L et al: Linkage studies in bi polar affective disorder with markers on chromosome21. J Affect Disord 1996; 41: 217-221.
17 Kwok JB, Adams LJ, Salmon JA et al: Nonparametric simulationbased statistical analyses for bipolar affective disorder locus on chromosome21q22.3. Am J Med Genet 1999; 88: 99-102.

18 Edenberg HJ, Foroud T, Conneally PM et al: Initial genomic scan of the NIMH genetics initiative bipolar pedigrees: chromosomes 3 , 5, 15, 16, 17, and 22. Am J Med Genet 1997; 74: 238-246.

19 Blackwood DH, He L, Morris SW et al: A locus for bipolar affective disorder on chromosome4p. Nat Genet 1996; 12: 427-430.

20 Aita VM, Liu J, Knowles JA et al: A comprehensivelinkage analysis of chromosome2lq22 supports prior evidence for a putative bipolar affective disorder locus. Am J Hum Genet 1999; 64: 210-217.

21 Freimer NB, Reus VI, Escamilla MA et al: Genetic mapping using haplotype, association and linkage methods suggests a locus for severe bipolar disorder (BPI) at 18q22-q23. Nat Genet 1996; 12: 436-441.

22 Ewald H, Degn B, Mors O, Kruse TA: Significant linkage between bipolar affective disorder and chromosome12q24. Psychiatr Genet 1998; 8: 131-140.

23 American Psychiatric Association: Diagnostic and Statistical Manual of Mental Disorders. APA Press: Washington DC, 1994

24 First MB, Spitzer RL, Gibbon M, Williams JBW: Structural Clinical Interview for DSM-IV Clinical Version (SCID-I/CV). American Psychiatric Press: Washington DC, 1997.

25 Ozkurkcugil A, Aydemir O, Yildiz M, Esen-Danaci A, Koroglu E: A validity of reliability study of Structured Clinical Interview for DSM-IV clinical version in Turkish population. J Drug Treatm (Turkish) 1999; 12: 233-236.

26 NIH/CEPH Collaborative Mapping Group: A comprehensive genetic linkage map of the human genome. Science 1992; 258: 67-86.

27 Gyapay G, Morissette J, Vignal A et al: The 1993-94 Généthon human genetic linkage map. Nat Genet 1994; 7: 246-339.

28 Buetow $\mathrm{KH}$, Weber JL, Ludwigsen $\mathrm{S}$ et al: Integrated human genome-wide maps constructed using the $\mathrm{CEPH}$ reference panel. Nat Genet 1994; 6: 391-393.

29 Dib C, Faure S, Fizames $C$ et al: A comprehensive genetic map of the human genome based on 5,264 microsatellites. Nature 1996; 380: 152-154.

30 Blouin JL, Christie DH, Gos A et al: A new dinucleotide repeat polymorphism at the telomere of chromosome2lq reveals a significant difference between male and female rates of recombination. Am J Hum Genet 1995; 57: 388-394.

31 Lathrop GM, Lalouel JM, Julier C, Ott J: Strategies for multilocus linkage analysis in humans. Proc Natl Acad Sci USA 1984; 81: 3443-3446.

32 Cottingham RWJ, Idury RM, Schaffer AA: Faster sequential genetic linkage computations. Am J Hum Genet 1993; 53: 252-263.

33 Detera-Wadleigh SD, Badner JA, Yoshikawa T et al: Initial genome scan of the NIMH genetics initiative bipolar pedigrees: chromosomes 4, 7, 9, 18, 19, 20, and 21q. Am J Med Genet 1997; 74: 254-262.

34 Pakstis AJ, Kidd JR, Castiglione CM, Kidd KK: Status of the search for a major genetic locus for affective disorder in the Old Order Amish. Hum Genet 1991; 87: 475-483.

35 Ewald $\mathrm{H}$, Eiberg $\mathrm{H}$, Mors $\mathrm{O}$ : A search for genes predisposing to manic depressive illness on chromosome20. Psychiatr Genet 1995; 5: 105-111.

36 Kruglyak L: Prospects for wholegenome linkage disequilibrium mapping of common disease genes. Nat Genet 1999; 22: 139-144. 